\title{
ASSOCIATION OF LEP-AND CTSF-GENOTYPES WITH LEVELS OF MEAT QUALITY PSE, NOR AND DFD IN PIGS OF LARGE WHITE BREED OF UKRAINIAN SELECTION
}

\author{
I. B. Bankovska ${ }^{1 *}$, Y. K. Oliinychenko ${ }^{1}$, V. N. Balatsky ${ }^{1}$, \\ T. V. Buslyk ${ }^{1}$, S. M. Hryshchenko ${ }^{2}$, R. L. Susol ${ }^{3}$ \\ ${ }^{1}$ The Institute of Pig Breeding and Agroindustrial Production, NAAS of Ukraine, 1, \\ Shvedska mohyla Str., Poltava, 36013, Ukraine \\ ${ }^{2}$ National University of Life and Environmental Sciences of Ukraine, 13, Heroyiv Oborony Str., Kyiv, 03041, Ukraine \\ ${ }^{3}$ Odesa State Agrarian University, 13, Panteleymonivska Str., Odesa, 65039, Ukraine \\ E-mail: gloryir2017@gmail.com*,olejliza@gmail.com,vnbalatsky@gmail.com,tvbuslyk@gmail.com, \\ s_grishchenko@ukr.net,kafedratvppt@ukr.net
}

Received December 05, 2019 / Received February 13, 2020 / Accepted March 20, 2019

\begin{abstract}
Aim. To study the distribution of genotypes by polymorphisms of the leptin (LEP SNP g.3469 T > C, LEP SNP g.2845 A > T) and cathepsin F (CTSF SNP g.22 C > G) genes according to the quality levels PSE, NOR and DFD meat in Large White pig breed of Ukrainian selection and to find associations of genetic markers with the total indicator of meat quality. Methods. We studied meat samples (m. longissimus dorsi) from 102 pigs of Ukrainian Large White breed, raised to the weight at slaughter of $120 \pm 5 \mathrm{~kg}$ in the experimental farm "Stepne" of the Poltava region, Ukraine. The ranking of muscle tissue was carried out according to the total indicator of meat quality (TM). PCR-RFLP analysis was used for DNA typing. The associations between genetic markers and TM were determined using ANOVA. Results. Genetic population analysis of Large White breed pigs of Ukrainian selection by genetic markers LEP SNP g.3469 T > C, LEP SNP g.2845 A > T and CTSF SNP g.22 $\mathrm{C}>\mathrm{G}$ was carried out. The informative value of LEP SNP g.2845 A $>$ T and CTSF SNP g.22 C $>$ G, according to the calculated polymorphism information content, was optimal for associative studies (PIC $=0.311$ and 0.373 , respectively). The distribution of meat samples by quality levels PSE, NOR and DFD was performed. Most of them had traits of moderately expressed $(n=22)$ and weakly expressed $(n=59)$ PSE defect (light, soft, exudative meat). The calculated coefficients of Chuprov's mutual conjugation between the genotypes for the studied SNPs and meat quality levels showed a moderate relationship between the genotypes for LEP SNP g.2845 A > T and CTSF SNP g.22 C > G and meat quality levels, $\mathrm{K}=0.26$ and 0.24 , respectively. According to the results of ANOVA, the differences were found between homozygous and heterozygous CTSF SNP g.22 $\mathrm{C}>\mathrm{G}$ genotypes in terms of the total indicator of meat quality. Conclusions. The meat of heterozygous pigs for CTSF SNP g.22 C > G (g.22GC) is characterized by a higher total indicator of meat quality (4.6) compared to the meat of homozygous animals g.22GG $(4.2, \mathrm{p} \leq 0.05)$ and g.22CC $(3.9, \mathrm{p} \leq 0.01)$.
\end{abstract}

Key words: pigs, population genetic analysis, genetic markers, leptin gene, cathepsin F gene, SNP, total indicator of meat quality.

DOI:

\section{INTRODUCTION}

Current breeding tendencies, aimed at increasing the meatiness of pig carcasses and intensification of pork production in severe conditions of technological stress,

(C) I. B. BANKOVSKA, Y. K. OLIINYCHENKO,

V. N. BALATSKY, T. V. BUSLYK, S. M. HRYSHCHENKO,

R. L. SUSOL, 2020 are considered to be generally determined factors, negatively affecting meat quality (Lourenco D et al, 2016). World practice still faces the negative side of this approach - there are less supplies of pork for the processing enterprises with the characteristics of normal quality (NOR), instead there are more frequent incidents of meat defects - PSE (pale, soft, exudative) and DFD (dark, firm, dry) which decrease its technological qual- 
ity and attractiveness for consumers considerably who often relate poor quality to the issues of food safety (Cassens R., 2000).

Meat with PSE defect has light color, soft loose structure, considerable release of meat juice due to low moisture-retaining ability and high active acidity (pH). In $24 \mathrm{~h}$ after the slaughter of pigs, the meat with DFD defect has dark color, dense location of fibers, $\mathrm{pH}$ level exceeding 6.3, high moisture-retaining ability, increased adhesiveness which is a favorable environment for the development of pathogenic microflora (Čobanović $\mathrm{N}$ et al, 2016).

Both defects have negative effect on economic efficiency of meat product processing due to the increase in additional expenses of enterprises for stabilization and improvement of material quality. In this aspect, the prediction and estimation of pork quality is of special relevance for successful production of a highquality product.

Recently, the novel breeding methods, based on typing pigs by genes, which are associated with productive traits of animals and belong to quantitative trait loci (QTL), are applied to solve problematic issues of the quantity and quality of pork meat. This approach was used as a basis for marker assisted selection (MAS) or gene assisted selection (GAS), the application of which accelerates considerably the process of selecting the desired genotypes and obtaining animals with planned productivity parameters. Leptin ( $L E P)$ and cathepsin F (CTSF) genes belong to QTL-genes or candidates for QTL. These are directly involved in controlling the finishing traits of pigs and the quality indices of meat and fat.

Leptin gene in the genome of pigs is localized in chromosome 18, it includes three exons and two introns (Bidwell A et al, 1997). Leptin is a key hormone of the energy exchange in the organism, involved in regulating appetite (Pankov Yu, 1999), insulin synthesis (Ishikawa $\mathrm{M}$ et al, 1998), functioning of genitourinary system (Munusamy S et al, 2015), impacting the reproductive function of animals and quantitative parameters of meat and fat (Kennes Y et al, 2001, de Oliveira Peixoto J et al, 2006). The effect of leptin is modulated via leptin receptors $(L E P R)$, whose corresponding gene is associated with productivity traits of pigs (Balatsky Vet al, 2016 a,b, Ros-Freixedes R et al 2016, Pérez-Montarelo D et al, 2013).

Cathepsins belong to the family of peptidase enzymes - proteinases, which are mainly located in ly- sosomes of skeletal muscles and have a wide spectrum of functions (Mammes O et al, Russo V et al, 1998). They participate in catabolism of the main proteins and have highly specific proteolytic activity. These enzymes are closely associated with the regulation of biochemical processes and activation of hormones and proenzymes (Piorkowska $\mathrm{K}$ et al, 2012) and are involved in the processing of antigens (Zavašnik $B$ and Turk B, 2006). Cathepsin F gene is located in pigs on chromosome 2, p14-p17, not far from cathepsin D genes and insulin-like growth factor 2. The latter is viewed as imprinting QTL for meat productivity traits of pigs (Laere A et al, 2003).

Many studies demonstrated the association of leptin and cathepsin F genes separately with some parameters of pig growth intensity, amount and quality of meat (Russo V et al, 2004, Davoli R et al, 2016, Ramos A et al, 2006). However, the level of productivity of animals is determined by a complex of interrelated characteristics, which depend on the impact of genetic and technological factors. For instance, meat with PSE and DFD defects is characterized by different indices of $\mathrm{pH}$, color, consistency, moisture-retaining ability. Therefore, the search for association between genetic markers and a complex of indicators or indices of productivity traits of pigs which consider different parameters and their mutual relations in the integrated way, is actually relevant among novel directions of modern research.

The aim of the work. To investigate the distribution of genotypes by single nucleotide polymorphisms (SNP) of leptin (LEP SNP g.3469 T > C, LEP SNP g.2845 $\mathrm{A}>\mathrm{T}$ ) and cathepsin $\mathrm{F}($ CTSF SNP g.22 $\mathrm{C}>\mathrm{G})$ genes by meat quality levels PSE, NOR and DFD in Large White pigs of Ukrainian selection and to find associations of genetic markers with the total indicator of meat quality (TM).

\section{MATERIALS AND METHODS}

The study was conducted using the ffattening pigs of Large White breed of Ukrainian selection (102 animals, including 52 sows and 50 castrated boars) in the experimental farm (EF) "Stepne" of the Institute of Pig Breeding and the Agroindustrial Production of NAAS in Poltava region. The animals were kept in group pens of 40 animals, raised till the weight at slaughter of $120 \pm 5 \mathrm{~kg}$ using the combined feeds of the own production. The level of feeding corresponded to the norms for finishing pigs by all the main indices (National Research Council, 2012). The combined feeds by two recipes were used with the addition of grain foundation, vegetative protein supplements and 
$2 \%$ premix, manufactured by AgroFeed company (Hungary). Control slaughter of experimental animals was done in the meat-processing shop of the farm. No additional sedatives were applied to the pigs.

Meat samples were taken from the longest back muscle ( $m$. longissimus dorsi) at the level of vertebrae 9-12 after $48 \mathrm{~h}$ aging of semi-carcasses at $+2-4{ }^{\circ} \mathrm{C}$. $1 \mathrm{~g}$ of muscle tissue was taken from each sample for genetic studies. Experimental animals, from whose carcasses the samples were further taken, were previously examined for the presence of the recessive allele of ryanodine receptor 1 ( $R Y R I)$, associated with stress sensitivity of pigs and thus with meat defects, in their genome (Ciepielewski Z et al, 2016). All animals had genotype g.1843CC, which excluded the impact of RYRl on meat quality indices.

According to the sequence of working methods and analysis of the results obtained, scientific investigations were conducted in three stages: population genetic analysis; distribution of meat samples of different genotypes by quality levels; search for association between genotypes and meat quality levels.

DNA was extracted from muscle tissue, using ionexchange resin Chellex-100 (Walsh $P$ et al, 2013). Genotyping by LEP SNP g.3469 T > C, LEP SNP g.2845 $\mathrm{A}>\mathrm{T}$ and CTSF SNP g.22 $\mathrm{C}>\mathrm{G}$ was conducted using PCR-RFLP with the consideration of the protocols, described in the articles (Kennes Y et al, 2001, de Olivei- ra Peixoto J et al, 2006, Russo V et al, 1998), the structure of primers and amplification conditions are presented in Table 1. The selection of primers and amplification conditions for PCR-amplification of DNA-fragment, containing LEP SNP g.2845 A > T, was done using Primer3Plus programme (Untergasser A et al, 2007)

PCR was conducted in $25 \mu \mathrm{l}$ (final volume) of the reaction mixture, containing $100 \mathrm{ng}$ of genomic DNA, $200 \mathrm{nM}$ of forward and reverse primers, $2.5 \mathrm{mM} \mathrm{MgCl}_{2}$, $0.25 \mathrm{mM}$ of each dNTP and one unit of recombinant Taq DNA-polymerase (Thermo Scientific, USA). The restriction of amplificates was conducted according to the protocol of the manufacturer (Thermo Scientific, USA) for each endonuclease used. The electrophoretic separation of restriction products was done in $2 \%$ agarose gel at the voltage of electric fields of $120 \mathrm{~V}$.

GENALEX 6 (Peakall R and Smouse P, 2006) was used to calculate population genetic parameters.

The distribution of muscle tissue by the manifestation of the corresponding quality characteristics was done by the method of determining the total indicator of meat quality (TM) (Lisitsyin A et al, 2008). This method was used to estimate: $\mathrm{pH}$ (with a portable device "LF-Star CPU-Pistole", Germany), the intensity of staining and consistency on the sample section (using the nine-point and five-point scales of special sensory evaluation tables respectively). The total indicator of meat quality was calculated by the formula: $\mathrm{TM}=5.4+$

Table 1. The structure of primers and conditions of PCR-amplification, restriction endonucleases and PCR-RFLP patterns of different alleles

\begin{tabular}{|c|c|c|c|c|c|}
\hline \multirow[b]{2}{*}{$\begin{array}{l}\text { Genes and } \\
\text { SNP }\end{array}$} & \multirow[b]{2}{*}{ Structure of primers } & \multicolumn{3}{|c|}{ Conditions of PCR-amplification } & \multirow[b]{2}{*}{$\begin{array}{l}\text { Restriction endonucleases } \\
\text { and PCR-RFLP patterns } \\
\text { of alleles }\end{array}$} \\
\hline & & $\begin{array}{c}\text { Size of } \\
\text { amplification } \\
\text { product (bp) }\end{array}$ & $\begin{array}{c}\text { Annealing } \\
\text { temperature } \\
\left({ }^{\circ} \mathrm{C}\right)\end{array}$ & $\begin{array}{l}\text { content } \\
\text { of } \\
\mathrm{MgCl}_{2} \\
(\mathrm{mM})\end{array}$ & \\
\hline$L E P$ & & & & & \\
\hline g. $2845 \mathrm{~A}>\mathrm{T}$ & $\begin{array}{l}\text { F:TGGCGAGCCTGGAGCAGT } \\
\text { R:GCAGCCTCCATCCCTAAGTGGG }\end{array}$ & 248 & 65 & 2.0 & $\begin{array}{l}\text { (XbalI): } \\
\text { allele g.2845A, } 242 \mathrm{bp} \\
\text { allele g.2845T, } 170+72 \mathrm{bp}\end{array}$ \\
\hline$L E P$ & & & & & \\
\hline g. $3469 \mathrm{~T}>\mathrm{C}$ & $\begin{array}{l}\text { F:AACAGAGGGTCACCGGTTTG } \\
\text { R:TTTGGAAGAGCAGCTTAGCG }\end{array}$ & 486 & 63 & 2.0 & $\begin{array}{l}(\text { Hinf } 1) \text { : } \\
\text { allele g.3469T } 486 \text { bp } \\
\text { allele g.3469C } 343+143 \text { bp }\end{array}$ \\
\hline $\begin{array}{l}C T S F \\
\text { g. } 22 \mathrm{G}>\mathrm{C}\end{array}$ & $\begin{array}{l}\text { F:AGGGAGGGCTGGAGACGGAGT } \\
\text { R:TCATTCTGGCTCAGCTCCAC }\end{array}$ & 118 & 58 & 2.0 & $\begin{array}{l}\text { (Rsa 1): } \\
\text { allele g.22G } 118 \mathrm{bp} \\
\text { allele g.22C } 97+21 \mathrm{bp}\end{array}$ \\
\hline
\end{tabular}


$+\mathrm{pH}+0.65 \cdot \mathrm{Z}+0.35 \cdot \mathrm{K}$, where $\mathrm{pH}-$ measured value of $\mathrm{pH} ; \mathrm{Z}$ - staining intensity; $\mathrm{K}$ - consistency.

Quality levels of muscle tissue corresponded to the expected quantitative value of TM. Extreme PSE (extr) $<1.50$, highly expressed PSE (high) $-1.51-2.50$, moderate PSE (mid) - 2.51-3.50, weakly expressed PSE (low) - 3.51-4.50, normal NOR - 4.51-5.50, weakly expressed DFD (low) - 5.51-6.50, moderate DFD (mid) - 6.51-7.50, highly expressed DFD (high) 7.51-8.50, extreme DFD (extr) > 8.51 (Lisitsyin A et al, 2008).

The associations between genetic markers and the total indicator of meat quality were investigated by ANOVA using Statistica 6.0 for Windows. The MS Excel 2007 package was used to calculate the statistical coefficient of Chuprov's mutual conjugation $(\mathrm{K})$ to study the relationship strength between the variation of two attributive traits. Coefficients acquire the values from 0 to 1 . The value of the coefficient, close to 1 , demonstrates closer relationship between the traits (Lackin G, 1990).

\section{RESULTS}

At the first stage of the study, specific population genetic parameters were determined for the group of pigs, used in the work, by genetic markers LEP SNP g.2845 A > T, LEP SNP g.3469 T > C and CTSF SNP g.22 $\mathrm{G}>\mathrm{C}$. The analysis results, presented in Table 2, demonstrate higher frequency of allele g. $22 \mathrm{C}$ by CTSF SNP g.22 G $>$ C. The highest number of animals had heterozygous genotype g.22CG (51 pigs), there were 31 animals with genotype g.22CC, and 20 animals - with genotype g.22GG.

Each genotype by CTSF SNP g.22 G $>$ C was presented with a different number of animals, the informative value of this genetic marker $(\mathrm{PIC}=0.373)$ was optimal for associative studies (Hao L et al, 2011).

A similar situation in terms of distribution of genotypes and informative value of the genetic marker was observed for $L E P$ SNP g.2845 A > T. In case of $L E P$ SNP g.3469 $\mathrm{T}>\mathrm{C}$ of the investigated group of animals were presented by two genotypes only, mostly g.3469TT. The frequency of the minor allele g.3469C was low, thus, the informative value of LEP SNP g.3469 T > C was beyond the range of the optimal one $(\mathrm{PIC}=0.136)$. It should be noted that the balance of genotypes by all the investigated SNP corresponded to the equilibrium (Graffelman $\mathrm{J}$ and Bruce $\mathrm{S}, 2018$ ), which is manifested in the value of $\chi^{2}$.

At the second stage of the study, the total indicator of meat quality was calculated for each meat sample under evaluation and the samples were distributed by the corresponding levels. Among 102 samples, 22 were characterized as the ones with PSE mid features, 59 were referred to PSE low, 18 samples had notable NOR meat qualities and 3 samples were found with DFD low features. In general, there was prevalence of meat samples with the characteristics, which had different intensity of PSE defect (81 samples).

Meat samples of different quality levels were distributed according to specific genotypes by each investi-

Table 2. The frequencies of alleles and genotypes and the informative value of genetic markers $L E P$ SNP g.2845 A $>$ T, $L E P$ SNP g.3469 T > C and CTSF SNP g.22 G > C

\begin{tabular}{|c|c|c|c|c|c|c|c|}
\hline \multirow{2}{*}{$\begin{array}{l}\text { Genetic marker } \\
\text { CTSF SNP }\end{array}$} & \multicolumn{2}{|c|}{ Frequencies of alleles } & \multicolumn{3}{|c|}{ Frequencies of genotypes $\mathrm{Ho} / \mathrm{He}$} & \multirow{2}{*}{$\frac{\chi^{2}}{0.014}$} & \multirow{2}{*}{$\begin{array}{c}\text { PIC } \\
0.373\end{array}$} \\
\hline & g. $22 \mathrm{C}$ & g. $22 \mathrm{G}$ & g. $22 \mathrm{CC}$ & g. $22 \mathrm{CG}$ & g.22GG & & \\
\hline g. $22 \mathrm{C}>\mathrm{G}$ & 0.55 & 0.45 & $\begin{array}{c}0.304 / 0.307 \\
(31)\end{array}$ & $\begin{array}{c}0.500 / 0.494 \\
(51)\end{array}$ & $\begin{array}{c}0.196 / 0.199 \\
(20)\end{array}$ & & \\
\hline LEP SNP & g. $2845 \mathrm{~A}$ & g. $2845 \mathrm{~T}$ & g.2845AA & g.2845AT & g.2845TT & 0.720 & 0.311 \\
\hline g. $2845 \mathrm{~A}>\mathrm{T}$ & 0.74 & 0.26 & $\begin{array}{c}0.539 / 0.555 \\
(55)\end{array}$ & $\begin{array}{c}0.412 / 0.380 \\
(42)\end{array}$ & $\begin{array}{c}0.049 / 0.065 \\
(5)\end{array}$ & & \\
\hline$L E P \mathrm{SNP}$ & g.3469T & g.3469C & g.3469TT & g.3469TC & g. $3469 \mathrm{CC}$ & 0.843 & 0.136 \\
\hline g.3469 T>C & 0.92 & 0.08 & $\begin{array}{c}0.833 / 0.840 \\
(85)\end{array}$ & $\begin{array}{c}0.167 / 0.153 \\
(17)\end{array}$ & $\begin{array}{c}0.000 / 0.007 \\
(0)\end{array}$ & & \\
\hline
\end{tabular}

Note: the number of animals for each genotype is presented in brackets; $\mathrm{H}_{\mathrm{o}}-$ observed heterozygosity; $\mathrm{H}_{\mathrm{e}}$ - expected heterozygosity; PIC - polymorphism information content; $\chi^{2}$ - value of criterion $\chi^{2}$ while estimating the significance of the deviation in the distribution of genotypes from Hardy-Weinberg equilibrium. 


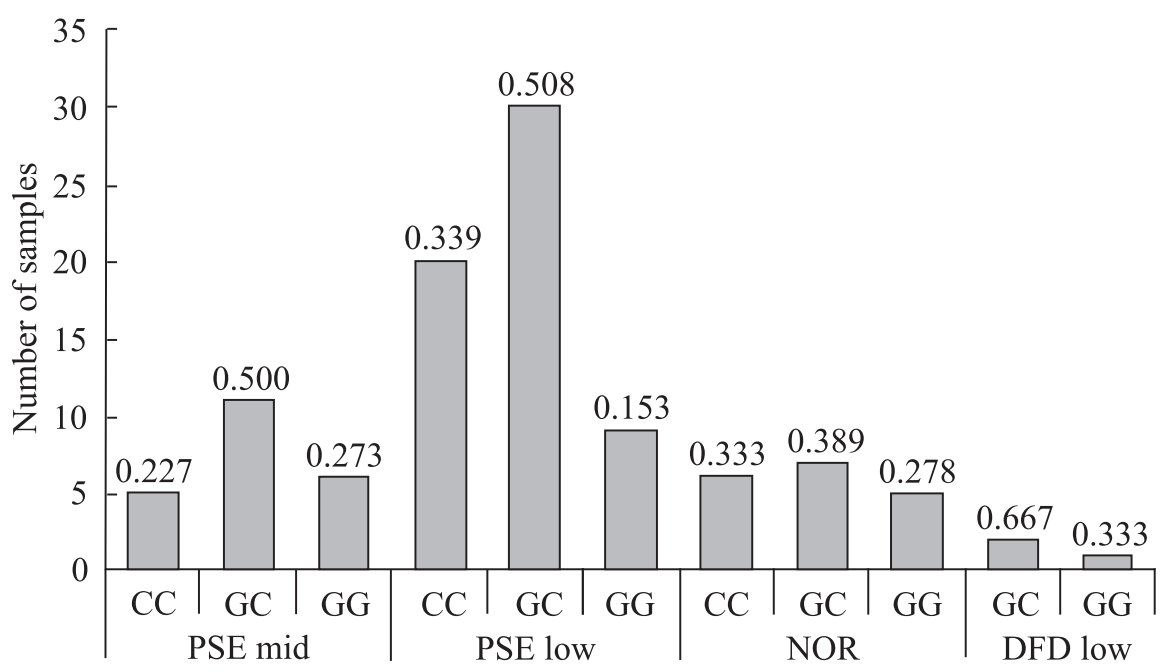

Fig. 1. The distribution and frequencies of genotypes by polymorphism of CTSF SNP g.22 C $>$ G by quality levels of muscle tissue

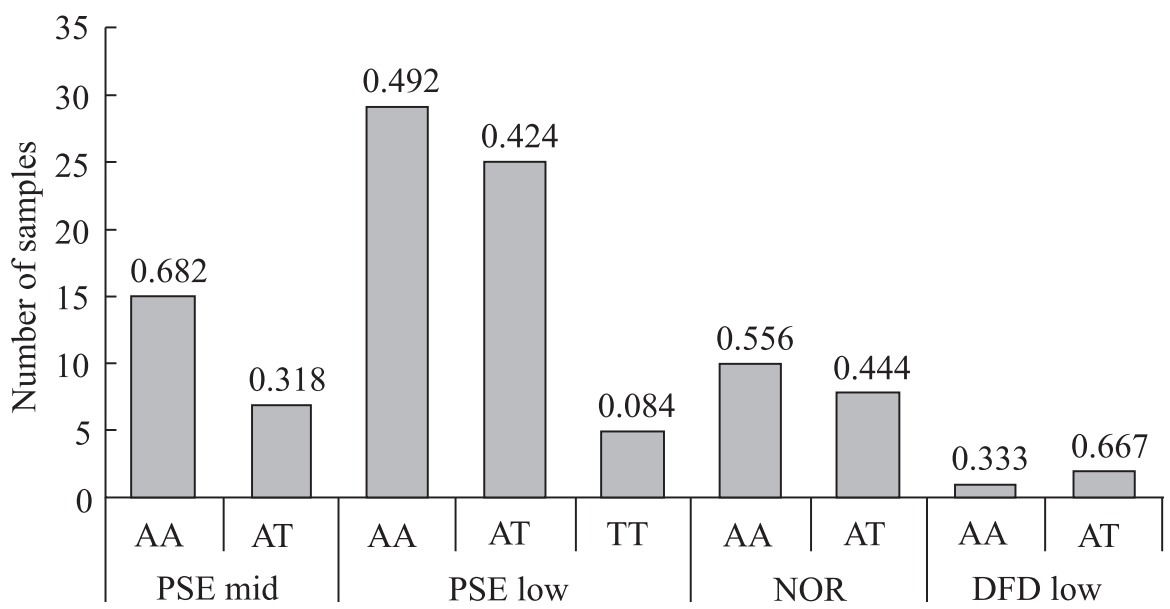

Fig. 2. The distribution and frequencies of genotypes by polymorphism of $L E P$ SNP g.2845 A $>$ T by quality levels of muscle tissue

gated polymorphism of genes. The results are presented in Fig. 1-3.

As for polymorphism of CTSF SNP g.22 C $>\mathrm{G}$, the animals with genotype g.22CG prevailed within each quality level. In the most numerous group, PSE low, the animals with genotype g.22CC were ranked second. In general, no obvious specificities were observed in the distribution of genotypes of samples depending on their belonging to the meat quality level. A similar distribution was observed for LEP SNP g.2845 A > T. In all the groups of samples with PSE quality characteristics, there were more animals with homozygous genotype g.2845AA and somewhat fewer animals with heterozygous g.2845AT. As for LEP SNP g.3469 $\mathrm{T}>\mathrm{C}$, the pigs with homozygous genotype g.3469TT, most frequently observed in our experiment, prevailed in all the groups by meat quality. Therefore, the distri- bution of genotypes by each SNP within each group of meat quality for each quality level of muscle tissue corresponded to their general distribution in the total sampling of animals.

At the third stage of the study, the search for the relationship between a specific allele or genotype was conducted using the genetic marker with a complex of traits. The calculations were done based on the analysis of the frequencies of alleles and genotypes of animals, differing in the manifestation of these traits (or selected in different directions regarding their manifestation). In our experiment, a complex of traits (complex evaluation) was the total indicator of meat quality, based on which meat samples were distributed into groups according to the quality levels PSE, NOR and DFD. The differences between the obtained distribution groups by frequencies of alleles and/or genotypes, detected at 


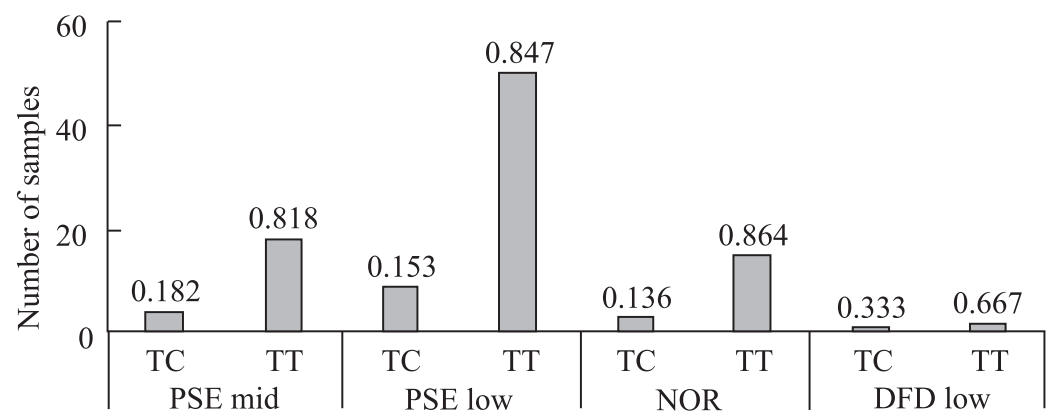

Fig. 3. The distribution and frequencies of genotypes by polymorphism of $L E P$ SNP g.3469T $>$ C by quality levels of muscle tissue

the previous stage of the study, may demonstrate the association between the latter and some levels of meat quality. However, the statistical analysis results did not manifest any registration of specific allele variants or genotypes for any determined level of meat quality.

Another approach to determining the associations between the mentioned polymorphisms and meat quality levels was the estimation of the coefficient of Chuprov's mutual conjugation between genotypes by the investigated SNP and meat quality levels. According to our results, presented in Table 3 , there is only a very weak relationship $(\mathrm{K}=0.05)$ between genotypes by LEP SNP g.3469 $\mathrm{T}>\mathrm{C}$ and meat quality levels. $\mathrm{K}=0.26$ and 0.24 between genotypes by SNPs LEP g.2845 A > T and CTSF g.22 C > G and meat quality levels respectively, which demonstrates a moderate relationship between them. However, the coefficient of Chuprov's mutual conjugation indicates only the existence of a relationship between two attributive features, in this case between genotypes by each SNP and meat quality levels PSE, NOR and DFD. This coefficient does not indicate which genotypes are associated with a higher or lower value of the total indicator of meat quality.
Thus, the relationship between SNPs and TM value was determined using ANOVA. It was determined that meat of heterozygous by CTSF SNP g. $22 \mathrm{C}>\mathrm{G}$ animals has a higher TM (4.6), compared to meat of homozygous pigs g. $22 \mathrm{CC}$ and g.22 $\mathrm{GG}(\mathrm{TM}=3.9$ and 4.2 , respectively), Table 3 . By the complex evaluation of TM, the meat of heterozygous pigs corresponds to the normal level of meat quality NOR, whereas the meat of pigs with genotypes g.22CC and g.22GG has features of PSE low. As for other SNP, their relationship with the total indicator of meat quality was not determined.

\section{DISCUSSION}

Genetic studies established that promising SNPs in the direction of elaborating genetic markers are mutations of leptin gene LEP g.2845 A > T and g.3469 T > C (Bidwell A, et al, 1997, Mammes O et al, 1998). Among foreign breeds of pigs, the animals with genotype TT by LEP SNP g.3469 T > C had lower average daily gain, higher thickness of backfat and lower content of intramuscular fat as compared to the animals with genotype TC (de Oliveira Peixoto $\mathrm{J}$ et al, 2006). As for polymorphism LEP SNP g.2845 A > T, there were discrepancies concerning the manifesta-

Table 3. The total indicator of meat quality of different genotypes by SNPs of leptin and cathepsin $\mathrm{F}$ genes, $\mathrm{X} \pm \mathrm{Sx}$

\begin{tabular}{|c|c|c|c|c|c|c|c|c|}
\hline \multirow{2}{*}{ Indicator } & \multicolumn{2}{|c|}{ LEP g.3469 T > C } & \multicolumn{3}{|c|}{$L E P$ g.2845 A > T } & \multicolumn{3}{|c|}{ CTSF g.22 C > G } \\
\hline & $\mathrm{TC}(17)$ & $\mathrm{TT}(85)$ & AA (55) & AT (42) & TT (5) & GG (20) & $\mathrm{GC}(51)$ & $\mathrm{CC}(31)$ \\
\hline $\mathrm{TM}$ & $3.9 \pm 0.20$ & $4.2 \pm 0.08$ & $4.1 \pm 0.11$ & $4.2 \pm 0.10$ & $4.0 \pm 0.54$ & $4.2 \pm 0.17$ & $4.6 \pm 0.11$ & $3.9 \pm 0.09$ \\
\hline $\mathrm{K}$ & \multicolumn{2}{|c|}{0.05} & \multicolumn{3}{|c|}{0.26} & \multicolumn{3}{|c|}{0.24} \\
\hline \multirow{2}{*}{$\mathrm{p} \leq$} & \multicolumn{2}{|c|}{$\mathrm{TC} / \mathrm{TT}$} & $\mathrm{AA} / \mathrm{AT}$ & $\mathrm{AT} / \mathrm{TT}$ & AA/TT & GG/GC & $\mathrm{GC} / \mathrm{CC}$ & $\mathrm{GG} / \mathrm{CC}$ \\
\hline & \multicolumn{2}{|c|}{0.14} & 0.62 & 0.74 & 0.82 & 0.05 & 0.01 & 0.18 \\
\hline
\end{tabular}

Note: TM - the total indicator of meat quality; $\mathrm{p}$ - significance level; $\mathrm{K}$ - coefficient of Chuprov's mutual conjugation; the number of animals in groups in presented in brackets. 
tion of better finishing and meat qualities in animals of different breeds with genotype TT (Kennes Y et al, 2001). No associations with meat quality indices were found, which forced us to study the mentioned genotypes in pigs of Large White of Ukrainian selection. We determined a moderate relationship between genotypes by LEP SNP g.2845 A > T and the total indicator of meat quality.

Cathepsins of skeletal muscles of pigs are known to play a relevant role in the process of autolysis and to be related to such meat defects as excessive softness, adhesiveness, dark color, metal taste, formation of white film on the section surface. The relationship between CTSF, meat tenderness and the content of intramuscular fat was studied in carcasses of crossbred pigs (Large White $\mathrm{x}$ Landrace) $\times \mathrm{Du}-$ roc) (Russo V et al, 2004, Davoli $\mathrm{R}$ et al, 2016). According to the results, obtained by Russo $\mathrm{V}$ et al (1998) in the study on pigs of Italian selection, the conclusion was made about the direct impact of gene CTSF on meat quality traits of pigs. Ramos R et al (2006) determined that genetic marker CTSF g. $22 \mathrm{G}>\mathrm{C}$ was significantly associated with color and $\mathrm{pH}$ of meat, content of intramuscular fat in Large White pigs of Italian selection. Our investigations demonstrated that Large White pigs of Ukrainian selection - heterozygotes g.22CG by CTSF SNP g.22 $\mathrm{C}>\mathrm{G}$ had a higher level of meat quality by the complex of interrelated quality indices (color, consistency, excudativeness and $\mathrm{pH}$ ).

Other authors determined the association between leptin and cathepsin F genes and the productivity indices for pigs. However, these relationships were determined for pigs of specific breeds of foreign selection and were also related to each investigated indicator separately, for instance, average daily gain, thickness of backfat, content of intramuscular fat, etc. The selected method of evaluating meat quality, based on the total indicator (Lisitsyin A et al, 2008) is comprehensive, calculated using the multiple regression equation. It allows distributing meat samples by quality levels PSE, NOR and DFD and analyzing a possible association between gene-markers and the manifestation of undesired defects in general. In our opinion, this approach ensures more focused investigation of genetic markers with the purpose of further targeted management of pork quality. It should be noted that associative investigations on the relationship between genetic markers and the total indicator of meat quality of pigs has not been previously conducted.

\section{CONCLUSIONS}

The evaluation of meat samples, taken from Large White pigs of Ukrainian selection, raised at SE EF "Stepne" of the Institute of Pig Breeding and the Agroindustrial Production of NAAS in Poltava region, in terms of more structured gradation of meat quality levels PSE, NOR and DFD, demonstrated a tendency towards the manifestation of pork characteristics with weakly expressed PSE low defect.

The associations were determined between genotypes by CTSF SNP g. $22>\mathrm{G}$ and the total indicator of meat quality. The meat of animals with genotype GC was characterized with a higher quality indicator (4.6) as compared to meat of animals with genotypes GG $(4.2, \mathrm{p} \leq 0.05)$ and $\mathrm{CC}(3.9, \mathrm{p} \leq 0.01)$. No association between markers of LEP SNP g.2845 A $>$ T and LEP SNP g.3469 T $>$ C and the total indicator of meat quality was detected.

Moderate correlative relationships were detected between the distribution of meat samples by quality levels and genotypes by the polymorphism of genes of LEP SNP g.2845 A > T and CTSF SNP g.22 C > G $(\mathrm{K}=0.26$ and 0.24 , respectively).

Further on, it is important to investigate the association between markers of leptin and cathepsin F and physico-chemical indices of meat and fat quality, which would ensure more precise characterization of the relationships and more valid substantiation for the determination of genetic markers in the sphere of forecasting pork quality.

Adherence to ethical principles. The protocol of experiments was approved by the Scientific council of the Institute of Pig Breeding and Agroindustrial Production of the National Academy of Agrarian Sciences of Ukraine. All the procedures, related to bioethical treatment of animals and slaughter, were conducted in compliance with the European Convention for the Protection of Vertebrate Animals used for Experimental and Other Scientific Purposes, Strasbourg, 1986.

Conflict of interests. The authors declare the absence of any conflicts of interests.

Support. The investigation was conducted with the support of the Institute of Pig Breeding and Agroindustrial Production of the National Academy of Agrarian Sciences (scientific project No. DR 0116U005008) and EU COST Action IPEMA (CA 15215).

Асоціації $L E P$ - та $C T S F$-генотипів з рівнями якості м'яса PSE, NOR i DFD у свиней великої білої породи української селекції 


\section{І. Б. Баньковська ${ }^{1}$ *, Є. К. Олійниченко ${ }^{1}$, В. М. Балацький ${ }^{1}$, Т. В. Буслик ${ }^{1}$, С. М. Грищенко ${ }^{2}$, Р. Л. Сусол ${ }^{3}$}

${ }^{1}$ Інститут свинарства і агропромислового виробництва НААН України, вул. Шведська могила, 1, м. Полтава, 36013, Україна

${ }^{2}$ Національний університет біоресурсів і природокористування України, вул. Героїв Оборони, 13, м. Київ, 03041, Україна

${ }^{3}$ Одеський державний аграрний університет, вул. Пантелеймонівська 13, м. Одеса, 65039, Україна

e-mail: gloryir2017@gmail.com*, olejliza@gmail.com, vnbalatsky@gmail.com,tvbuslyk@ gmail.com, s_grishchenko@ukr.net, kafedratvppt@ukr.net

Мета. Дослідити розподіл генотипів за поліморфізмами генів лептину (LEP SNP g.3469 T > C, LEP SNP g.2845 A > T) та катепсину F (CTSF SNP g.22 C > G) за якісними рівнями м'яса PSE, NOR i DFD у свиней великої білої породи української селекції та встановити асоціації генетичних маркерів з сумарним показником якості м'яса. Методи. Досліджували зразки м'яса ( $m$. longissimus dorsi) 102 голів свиней великої білої породи української селекції, вирощених до живої маси $120 \pm 5$ кг в умовах дослідного господарства «Степне» Полтавської області. Ранжування м'язової тканини проводили у відповідності з сумарним показником якості м'яса (CM). Для ДНК типування використовували ПЛР-ПДРФ аналіз. Асоціації між генетичними маркерами та СМ визначали за допомогою однофакторного дисперсійного аналізу. Результати. Проведено генетико-популяційний аналіз у стаді свиней великої білої породи української селекції за генетичними маркерами LEP SNP g.3469 T > C, LEP SNP g.2845 A > T i CTSF SNP g.22 C > G. Інформативність LEP SNP g.2845 A $>$ T і CTSF SNP g.22 C > G, згідно розрахованого інформаційного змісту поліморфізму, виявилася оптимальною для асоціативних досліджень в стаді (PIC $=0,311$ і 0,373, відповідно). Проведено розподіл зразків м'яса за рівнями якості PSE, NOR i DFD. Більшість 3 них мали ознаки помірно вираженої $(\mathrm{n}=22)$ та слабо вираженої $(\mathrm{n}=59)$ вади PSE (м'ясо світле, м'яке, ексудативне). Розрахований коефіцієнт взаємної спряженості Чупрова між генотипами за досліджуваними SNP та рівнями якості м'яса свідчив про існування помірного зв'язку між генотипами за LEP SNP g.2845 A > T та CTSF SNP g.22 $\mathrm{C}>\mathrm{G}$ і рівнями якості м'яса, $\mathrm{K}=0,26$ та 0,24 , відповідно. За результатами однофакторного дисперсійного аналізу встановлені відмінності між гомозиготними та гетерозиготними генотипами за CTSF SNP g.22 C > G за сумарним показником якості м'яса свиней. Висновки. М'ясо свиней гетерозиготних за CTSF SNP g.22 C > G (g.22GC) характеризується більш високим сумарним показником якості $(4,6)$, ніж м'ясо гомозиготних тварин g. $22 \mathrm{GG}(4,2, \mathrm{p} \leq 0,05)$ i g.22CC $(3,9, \mathrm{p} \leq 0,01)$.
Ключові слова: свині, генетико-популяційний аналіз, генетичні маркери, ген лептину, ген катепсину F, SNP, сумарний показник якості м'яса.

\section{Ассоциации $L E P$ - и $C T S F$-генотипов с уровнями качества мяса PSE, NOR и DFD у свиней крупной белой породы украинской селекции}
И. Б. Баньковськая ${ }^{1}$, Е. К. Олейниченко ${ }^{1}$, В. Н. Балацкий ${ }^{1}$, Т. В. Буслик ${ }^{1}$, С. М. Грищенко ${ }^{2}$, Р. Л.Сусол ${ }^{3}$

${ }^{1}$ Институт свиноводства и агропромышленного производства НААН Украины, ул. Шведская могила, 1, м. Полтава, 36013, Украина

${ }^{2}$ Национальный университет биоресурсов и природоиспользования Украины ул. Героев Обороны, 13 , г. Киев, 03041, Украина

${ }^{3}$ Одесский государственный аграрный университет, ул. Пантелеймоновская, 13, г. Одесса, 65039, Украина

e-mail: gloryir2017@gmail.com*, olejliza@gmail.com, vnbalatsky@gmail.com, tvbuslyk@gmail.com,s_grishchenko@ukr.net, kafedratvppt@ukr.net

Цель. Изучить распределение генотипов по полиморфизмам генов лептина (LEP SNP g.3469 T > C, LEP SNP g.2845 A > T) и катепсина F (CTSF SNP g.22 C > $>$ G) по уровням качества мяса PSE, NOR и DFD у свиней крупной белой породы украинской селекции и установить ассоциации генетических маркеров с суммарным показателем качества мяса. Методы. Исследовали образцы мяса (m. longissimus dorsi) 102 голов свиней крупной белой породы украинской селекции, выращенных до живой массы $120 \pm 5$ кг в условиях опытного хозяйства «Степное» Полтавской области. Ранжирование мышечной ткани проводили в соответствии с суммарным показателем качества мяса (CM). Для ДНК типирования использовали ПЦР-ПДРФ анализ. Ассоциации между генетическими маркерами и СМ определяли с помощью однофакторного дисперсионного анализа. Результаты. Проведен генетико-популяционный анализ в стаде свиней крупной белой породы украинской селекции по генетическим маркерам $L E P$ SNP g. 3469 T > C, LEP SNP g.2845 A > T и CTSF SNP g.22 $\mathrm{C}>\mathrm{G}$. Информативность LEP SNP g.2845 A > Т и CTSF SNP g.22 C > G, согласно показателя информационного содержания полиморфизма, оказалась оптимальной для проведения ассоциативных исследований в стаде (PIC = $=0,311$ i 0,373, соответственно). Выполнено распределение образцов мяса по уровням качества PSE, NOR и DFD. Большинство из них имели признаки умеренно выраженного $(\mathrm{n}=22)$ и слабо выраженного $(\mathrm{n}=59)$ дефекта PSE (мясо светлое, мягкое, экссудативное). Рассчитанные коэффициенты взаимной сопряженности Чупрова между генотипами по исследуемым SNP и уровнями качества мяса свидетельствовали о существовании 
умеренной связи между генотипами по LEP SNP g.2845 $\mathrm{A}>\mathrm{T}$ и CTSF SNP g.22 C $>\mathrm{G}$ и уровнями качества мяса, $\mathrm{K}=0,26$ и 0,24 , соответственно. По результатам однофакторного дисперсионного анализа установлены отличия между гомозиготными и гетерозиготным генотипами по CTSF SNP g.22 C > G по суммарному показателю качества мяса свиней. Выводы. Мясо свиней гетерозиготных по CTSF SNP g.22 C > G (g.22GC) характеризуется более высоким суммарным показателем качества $(4,6)$, чем мясо гомозиготных животных g.22GG $(4,2, \mathrm{p} \leq 0,05)$ и g. $22 \mathrm{CC}(3,9, \mathrm{p} \leq 0,01)$.

Ключевые слова: свиньи, генетико-популяционный анализ, генетические маркеры, ген лептина, ген катепсина F, SNP, суммарный показатель качества мяса.

\section{REFERENCES}

Balatsky V, Bankovska I, Pena RN. et al. (2016a) Polymorphisms of the porcine cathepsins, growth hormonereleasing hormone and LEPtin receptor genes and their association with meat quality traits in Ukrainian Large White breed. Mol. Biol. Rep. 43:517-26. doi:10.1007/ s11033-016-3977-z.

Balatsky V, Bankovska I, Saienko A. (2016b) Association between $L E P$ tin receptor gene polymorphism and quality of both meat and back fat in large white pigs of Ukrainian breeding. Agr. Sci. Pract. 3(2):42-8. doi:10.15407/ agrisp3.02.042.

Bidwell A, Ji S, Frank C. et al. (1997) Cloning and expression of the porcine obese gene. Anim. Biotech. 8:192-206. doi: 10.1080/10495399709525882.

Cassens RG. (2000) Historical perspectives and current aspects of pork meat quality in the USA. Food Chemistry 69:357-63. doi: 10.1016/s0308-8146(00)00048-0

Ciepielewski ZM, Stojek W, Borman A. et al. (2016) The effects of ryanodine receptor (RYR1) mutation on natural killer cell cytotoxicity, plasma cytokines and stress hormones during acute intermittent exercise in pigs. Res. Vet. Sci. 105:77-86. doi: 10.1016/j.rvsc. 2016.01.012.

Čobanović N, Karabasil N, Stajković S. et al. (2016) The influence of pre-mortem conditions on pale, soft and exudative (PSE) and dark, firm and dry (DFD) pork meat. Acta Veter. 66(2):172-86. doi: 10.1515/acve2016-0015.

Davoli R, Cristina Z, Paolo B. et al. (2016) Association study between single nucleotide polymorphisms in porcine genes and pork quality traits for fresh consumption and processing into Italian dry-cured ham. Meat Sci. 126:7381. doi: 10.1016/j.meatsci.2016.11.018.

de Oliveira Peixoto J, Facioni C, Lopes S. et al. (2006) Associations of LEPtin gene polymorphisms with production traits in pigs. J. Anim. Breed. Genet. 123(6):3715. doi: 10.1111/j.1439-0388.2006.00611.x.

European Convention for the Protection of Vertebrate Animals used for Experimental and Other Scientific
Purposes, Strasbourg, 18.III.1986. http://conventions. coe.int/treaty/en/treaties/html/123.

Graffelman J, Bruce S. (2018) Multi-allelic exact tests for Hardy-Weinberg equilibrium that account for gender. Mol. Ecol. 18(3):461-73. doi: 10.1111/1755-0998.12748.

Hao LL, Yu H, Zhang Y. (2011) Single nucleotide polymorphism analysis of exons 3 and 4 of IGF-1 gene in pigs. Genet. Mol. Res. 10:1689-95. doi: 10.4238/vol10-3 gmr1328.

Ishikawa M, Pruneda M, Adams Huet B. et al. (1998) Obesity independent hyperinsulinemia in nondiabetic first degree relatives of individuals with type 2 diabetes. Diabetes. 47(5):788-92. doi: 10.2337/diabetes.47.5.788.

Kennes Y, Murphy B, Palin M. (2001) Characterization of swine LEPtin (LEP) polymorphisms and their association with production traits. Anim. Genet. 32:215-8. doi: 10.1046/j.1365-2052.2001.00768.x.

Lackin G. (1990) Biometriya. Editorial service, p. 352

Laere AS, Nguyen M, Braunschweig M. et al. (2003) A regulatory mutation in IGF2 causes a major QTL effect on muscle growth in the pig. Nature. 425:832-6. doi: 10.1038/nature02064.

Lisitsyin A, Lipatov N, Kudryashov L. (2008) Teoriya i praktika pererabotki myasa. Moskow. Editorial service, p. 305 [in Russian].

Lourenco DA, Tsuruta S, Andonov S. et al. (2016) Modeling response to heat stress in pigs from nucleus and commercial farms in different locations in the United States. J. Anim. Sci. 94(11):4789-98. doi: 10.2527/jas. 2016-0536.

Mammes O, Betoulle D, Aubert R. (1998) Novel polymorphism in the 5' region of LEP gene. Diabetes. 47 : 487-9. doi: $10.2337 /$ diabetes.47.3.487.

Munusamy S, Carmo J, Hosler J. et al. (2015) Obesityinduced changes in kidney mitochondria and endoplasmic reticulum in the presence or absence of LEPtin. Physiol. Renal. Physiol. 309(8):121-39. doi: 10.1152/ ajprenal.00188.2015.

National Research Council (2012) Nutrient Requirements of Swine: Eleventh Revised Edition. Washington, DC: The National Academies Press. doi: 10.17226/13298.

Pankov Yu. (1999) Adipose tissue as an endocrine organ regulating growth, puberty, and other physiological functions. Biochemistry. 64:601-9.

Peakall R, Smouse PE. (2006) GENALEX 6: genetic analysis in Excel. Population genetic software for teaching and research, Mol. Ecol. Not. 6(1):288-95. doi: 10. 1111/j.1471-6.2005.01155.x.

Pérez-Montarelo D, Fernández A, Barragán C. et al. (2013) Transcriptional Characterization of Porcine Leptin and Leptin Receptor Genes. PLoS One. 8(6):e66398. doi: 10.1371/journal.pone.0066398.

Piorkowska K, Ropka-Molik K, Eckert R. et al. (2012) The association between polymorphisms of three cathepsins and economically important traits in pigs raised 


\section{ASSOCIATION OF LEP-AND CTSF-GENOTYPES WITH LEVELS OF MEAT QUALITY PSE}

in Poland. Livest. Sci. 150:316-23. doi: 10.1016/j. livsci.2012.09.022.

Primer blast design tool $<$ https://www.ncbi.nlm.nih.gov/tools primer-blast / index . c gi ? OR G A N I S M = 1235996\&INPUT_SEQUENCE $=$ JX869059.1\&LINK_ LOC $=$ nuccore $>$.

Ramos AM, Helm J, Sherwood D. et al. (2006) Mapping of 21 genetic markers to a QTL region for meat quality on pig chromosome 17. Anim. Genet. 37:296-7. doi: 10.1111/j.1365-2052.2006.01437.x.

Ros-Freixedes R., Gol S., Pena RN. (2016) Genome-Wide Association Study Singles Out SCD and LEPR as the Two Main Loci Influencing Intramuscular Fat Content and Fatty Acid Composition in Duroc Pigs. PLoS One. 11(3):e0152496. doi: 10.1371/journal.pone.0152496.

Russo V, Davoli R, Nanni Costa L. et al. (1998) Association of the CTSB, CTSF and CSTB genes with growth, car- cass and meat quality traits in heavy pigs. Ital. J. Anim. Sci. 2:67-9. doi: 10.4081/ijas.2003.11675917.

Russo V, Fontanesi L, Davoli R. et al. (2004) Linkage mapping of the porcine cathepsin F (CTSF) gene close to the QTL regions for meat and fat deposition traits on pig chromosome 2. Anim. Genet. 35:155-7. doi: 10.1111/j.1365-2052.2004.01105.x.

Untergasser A, Nijveen H, Rao X. et al. (2007) Primer3Plus, an enhanced web interface to Primer3. Nucl. Acids. Res. 35(2):71-4. doi: org/10.1093/nar/gkm306.

Walsh PS, David A. Metzger DA. et al. (2013) Chelex 100 as a Medium for Simple Extraction of DNA for PCRBased Typing from Forensic Material BioTechniques. 54(3):134-9. doi: 10.2144/000114018.

Zavašnik BT, Turk B. (2006) Cysteine cathepsins in the immune response. Tissue antigens. 67(5):349-55. doi: 10 . 1111/j.1399-0039.2006.00585.x. 